\title{
JOHN A. NIEMI IN MEMORIUM
}

Monen suomalaisen aikuiskasvattajan kunnioittama aikuiskasvatuksen professori John A. Niemi menehtyi vaikeaan sairauteen DeKalbissa Illinoisissa Yhdysvalloissa 6. heinäkuuta 200471 vuoden ikäisenä.

Hänen isovanhempansa muuttivat aikoinaan Yhdysvaltoihin etsimään parempaa elämää joutuen kuitenkin alistumaan sielläkin pientilallisen arkeen. Hänen isänsä työskenteli kaivoksissa ja äiti hoiti kotia. Jo nuorena tapahtuneen onnettomuuden johdosta hänen toinen jalkansa oli lyhyempi kuin toinen. Niemi oppi, että elämässä tärkeiden asioiden eteen täytyy tehdä työtä. Hän myös tiedosti huolenpidon, välittämisen ja tukemisen merkityksen ihmiselle.

Niemi työskentelikin erilaisissa opetustehtävissä yli 50 vuotta elämästään tullen tunnetuksi siitä, että hän aidosti välitti opiskelijoistaan. Hän innosti lukemattomia aikuisia opintojen pariin ja kantoi heistä huolta paljon sen jälkeen, kun he valmistuivat opinnoistaan. Hänen ansioistaan opettajana Northern Illinois Universityssä hänelle myönnettiin arvonimi 'Presidential Teaching Professor'.

Paitsi opettaja, Niemi oli aikuiskasvatustieteen alalla ansioitunut asiantuntija, jolla oli monipuolinen ammatillinen tausta ja laaja yhteistyökumppanien verkosto. Hän toimi mm. Yhdysvaltain aikuiskasvatuksen professoreiden järjestön puheenjohtajana, julkaisi satoja kirjoja ja artikkeleja aikuiskasvatustieteen alueelta sekä piti lukemattomia kutsuvierasesitelmiä eri puolilla maailmaa. Hän oli eräs aikamme kansainvälisesti tunnetuimmista aikuiskasvattajista.

Niemen rakkaus Suomeen oli suuri. Hän toimi 1970-luvulta lähtien monenlaisissa asiantuntijatehtävissä Suomessa. Hän oli mm. Fulbright-professorina käynnistämässä aikuiskasvatustieteen opetusta Helsingin yliopistossa ja yliopistollista täydennyskoulutusta Helsingin yliopiston Lahden tutkimus- ja koulutuskeskuksessa (nyk. Koulutus- ja kehittämiskeskus Palmenia). Hänelle myönnettiin kunniatohtorin arvo Helsingin yliopistosta 1986.

Niemi järjesti Yhdysvaltalaisille aikuiskasvatustieteen opiskelijoille ja asiantuntijoille monia vierailuja Suomeen. Useat kansainväliset alan konferenssit ja tapaamiset Suomessa olivat Niemen aikaansaamia. Kaiken kaikkiaan hän vieraili
Suomessa 20 kertaa. Vastaavasti hän järjesti ohjausta ja kursseja Yhdysvalloissa suomalaisille asiantuntijoille sekä mahdollisti useiden tutkijoiden jatko-opiskelun kotiyliopistossaan Northern Illinois Universityssä.

Niemi edisti toiminnallaan sekä Suomessa että Yhdysvalloissa suuresti suomalaisuutta. Amerikansuomalaiset myönsivät hänelle Finn Festissä 1994 Fabulous Finn Award

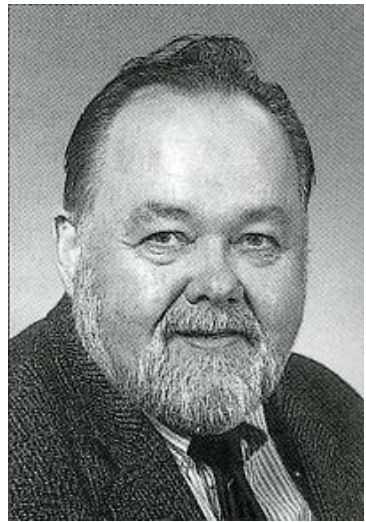

John A. Niemi -palkinnon suomalaisen kasvatuksen, kulttuurin ja perinteen edistämisestä. Hänelle myönnettiin ansioistaan suomalaisuuden edistämisessä Suomen Leijonan ritarikunnan kunniamerkki vuonna 2001.

John A. Niemi teki vuosikymmeniä pyyteetöntä työtä suomalaisen aikuiskasvatuksen edistämiseksi järjestäen mahdollisuuksia eri verkostojensa kautta monille opiskelijoille, tutkijoille ja muille asiantuntijoille. Hän toteutti omalla esimerkillään aikuiskasvatuksen parhaita periaatteita rohkaisten ja tukien opiskelijoitaan ja kollegoitaan vaativimpiin alan tehtäviin. Hänet tunnettiin loputtomasta ystävällisyydestään, sinnikkyydestään ja energisyydestään. Kenellekään hänet tunteneelle ei jäänyt epäselväksi, mitä viime kädessä tarkoittaa suomalainen sisu. Johnia jää kaipaamaan suuri joukko suomalaisia aikuiskasvattajia.

\section{Antti Kauppi}

\section{"I HOPE HIS EXAMPLE WILL LIVE ON"}

I will remember John Niemi. During our 28 years as friends and colleagues he tried to mentor me. We wrote, taught, traveled, fought and played together. He taught me a lot. I hope his example will live on.

John was a leader and an important influence to the field of adult education both in the United States and in Finland. His perspective was one of 
social inclusion, humanistic values, and diversity initiatives. He believed in Finnish idealism and what adult education can do to bring people together, to promote equality, decency, and fair play. His research centered on Human Resource Development, in public, governmental, and voluntary contexts. People close to him know that he was a strong advocate for his causes and for his people. He represented the view that people matter more than technology or the institutions in which they work. John always knew that along side scholarship there is also a rightful place for personal choices and values. John strictly believed that one's development of a sense of mission matters as much as the cultivation of the intellect and he held his students accountable for both. Contextually, he fought for the rights of marginalized groups of people to be heard, for all of our voices to matter, and he helped us to see that adult education ought to be an expansive practice, not a delimiting or an elitist movement.

John will be remembered as a man of compassion and vision. We could use such attributes about now, as we increasingly face narrowing conceptions of scholarship, not multi-disciplinary practice, over-specialization and restrictive standards, not expansiveness or global visioning, and lines of demarcation strictly defining "we" versus "they," not a spirit of inclusion. During this time of increasing global tensions and protectivism perhaps we would to well to add to our heritage the admonitions of this great pioneer of adult education, that the answers are to be found in our compassion for others, effective practices of inclusion of divergent perspectives, and a heightened sense of a global perspective. At its best, adult education raises our collective consciousness. We can remember John A. Niemi for that. 